\title{
Kaisa Ilmonen
}

\section{Miten romaanilaji sääntelee vapautta? Karibialainen kirjallisuus ja paikoiltaan siirtynyt kehitysromaani}

Viimeaikaisessa postkoloniaalisessa maailmankirjallisuudessa kehitysromaania lajina on käytetty paljon: yhä uudestaan monikulttuuriset kirjailijat hyödyntävät lajin muotoja rakentaakseen identiteettiä kulttuurien välissä. Bildungsromania on pidetty kirjallisuuden historiassa yleisesti saksalaiseen täysromantiikkaan kytkeytyvänä muotona, modernin subjektin kehkeytymisen tai tulemisen symbolisena ilmauksena. Se on perustaltaan kytköksissä länsimaisen modernin yksilökeskeisyyteen ja eurosentriseen valistuksen projektiin. Kehitysromaanissa kuvataan usein prosessi, jossa päähenkilö tiettyjen valintojen ja hänen tielleen sattuvien esteiden voittamisen jälkeen pystyy ikään kuin kasvamaan omaksi itsekseen. Hänen on tämän prosessin kuluessa ollut mahdollista määrittää oma ainoalaatuinen suhteensa todellisuuteen. Voitaisiinkin väittää, että se on laji, jossa institutionalisoituu tapa esittää emansipoitunut, yksilöllinen ja koherentti minuus. ${ }^{1}$

Tässä artikkelissa pohdin, mikä on jälkikoloniaalinen kehitysromaani ja miten ei-eurooppalaisen identiteetin rakentumisen prosessia - vapautta määrittää minuus - sääntelee eurooppalainen Bildung-genre. Keskityn erityisesti karibialaisen kulttuurialueen kirjallisuuteen, jossa kehitysromaani on ollut suosittu. Tarkastelen, mitä kehitysromaanille lajina tapahtuu sen "muuttaessa" entisiin siirtomaihin eli miten perinteinen kehitysromaani ja ei-eurooppalainen identiteetti törmäävät. Kiinnostavaa on, että huomattavan suuri osa esimerkiksi 1980-luvulla kirjallisen uransa aloittaneista karibialaisista naiskirjailijoita on kirjoittanut kehitysromaanin. Keskitynkin artikkelissani tuonnempana päsiassa juuri näihin teoksiin. Pohdin, mikä tästä romaanilajista tekee niin sovellettavan ja vetovoimaisen, että siihen sisäänrakennettu tarina minän tulemisesta omaksi itsekseen toistuu uudelleen ja uudelleen? Millainen on tämä Bildungsroman joutuessaan diasporaan, eli millaisia piirteitä se saa irrotessaan saksalaisesta traditiostaan ja muuttuessaan hybridiksi? Miten laji toimii vapauden sääntelijänä määriteltäessä emansipoituvaa, postkoloniaalista minää?

\section{Karibialaisen kirjallisuuden traditio}

Imperiumin varjossa kasvaneilla tytöillä ei juuri ole ollut puheenvuoroa kirjallisuuden historiassa. Poikkeuksen tekee kuitenkin Karibian alue, jossa naiskirjallisuudella on 
voimakkaat juuret Karibian ensimmäiseksi romaaniksi usein nimitetystä teoksesta The History of Mary Prince, a West Indian Slave, Related by Herself vuodelta 1831 alkaen. Karibialaisen kehitysromaanin kontekstissa tärkeä kirjailija oli jamaikalaissyntyinen Claude McKay, eräs Harlemin renessanssin johtohahmoista. McKay matkusteli laajasti Euroopassa, ja hän sai voimakkaita vaikutteita 1800-luvun romantiikasta. Hänen ehkä tunnetuin teoksensa Banana Bottom vuodelta 1933 on Jamaikalle sijoittuva nuoren naisen kasvutarina englantilaisen sivistyksen kyseenalaistamisesta ja oman kulttuurin tavoittamisesta. Englantilaistumisen tai ranskalaistumisen jälkeistä kautta leimaa Karibialla négritude-liike, joka korosti voimakkaasti afrikkalaisten juurien etsintää sekä paluuta afrikkalaiseen historiaan ja kulttuuriperintöön. ${ }^{2}$

Robert Aldrichin mukaan näkemykset kreolikulttuurista ja moniäänisyydestä alkoi vat yleistyä 1960-luvulla. Yhtenä ajatusten taustahahmoista toimi kirjailija Edouard Glissant, joka vaati länsi-intialaista kulttuuria keskittymään karibialaisuuteen itseensä sen monine hybridisine piirteineen. Merkittävää ei hänen mukaansa ollut kolonialistinen Eurooppa tai myyttinen Afrikka vaan kreolikulttuurin synkreettisen moninaisuuden hyväksyminen ja arvostus (Aldrich 1995, 113-114). Toisaalta 1960-luku oli niin afrikkalais-amerikkalaisen kuin afrikkalais-karibialaisenkin kirjallisuuden kontekstissa monenlaisten emansipatoristen liikkeiden aikaa. Bildungsroman saattoi muotona tarjota affirmatiivisia tarinoita poliittiseen taisteluun. Englantilaisen koulutuksen saaneet barbadoslaiset, George Lamming ja Austin Clarke, hyödynsivät tietoisesti eurooppalaisia malleja kehitysromaaneissaan. Heidän teoksissaan henkilökohtaisen kehityksen kuvaaminen on kuitenkin väline kuvata laajemmin kolonialismin vaikutuksia koko yhteisöön. 1970-luvulla karibialainen kirjallisuus tarttui erilaisten rajojen ja alistavien määrittelyjen teemoihin. Monet tuon ajan romaanit tarkastelivat yksilön vieraantumista ja epätoivoa - jopa hulluutta - karibialaisessa "historiattomassa" kulttuurissa ja pohtivat erilaisia luokkaan sekä rotuun liittyviä etuoikeuksia suhteessa karibialaiseen identiteettiin. Vieraantuneisuus kodista, paikattomuus ja muutot liittyivät kaunokirjallisuuden keskeisiin kysymyksiin. Teemoja pohdittiin usein lapsipäähenkilöiden kasvua ja koulunkäyntiä kuvaavassa omaelämäkerrallisessa kirjallisuudessa. Tässä autobiografisessa fiktiossa myös tyttöpäähenkilöt yleistyivät, kuten Merle Hodgen vuonna 1970 ilmestyneessä teoksessa Crick Crack Monkey.

Hodgen klassikkoteosta on erityisen kiinnostavaa tarkastella nimenomaan kolonialistisena kehitysromaanina, sillä se kuvaa karibialaisen tyttösubjektin kehkeytymistä pikemminkin ulkopuoliseksi kuin eheäksi eli hidasta siirtymistä kulttuurisen ja sukupuolisen toiseuden tilaan sekä identiteetin paikoiltaan siirtymistä. Karibialaisen naiskirjallisuuden yhteydessä Bildungsprosessia onkin joskus kutsuttu "surulliseksi initiaatioksi” (Leseur 1995, 150). Kehitystarina on valjastettu kuvaamaan päähenkilön ymmärrystä kolonialististen, seksististen ja rodullisten realiteettien paineesta, jossa 
loppua määrittää pikemminkin kulkeutuminen kohti identiteetin fragmentaarisuutta tai neuroottista minäkuvaa kuin eheyttä. Tälle antagonistiselle naisen romahtamista kuvaavalle romaanille oli tarjonnut mallin 1966 julkaistu, Dominican saarelta kotoisin olevan Jean Rhysin teos Wide Sargasso Sea. Toisaalta 1960- ja -70-luvut ovat karibialaisessa kirjallisuudessa myös erilaisten identiteettipolitiikkojen aikaa, jolloin tietoisuus omista juurista alkoi saada yhä enemmän tilaa. ${ }^{3}$

1980-luku merkitsi karibialaisessa kirjallisuudessa naiskirjailijoiden voimakasta esiinmarssia. Monet nuoret naiset, kuten Michelle Cliff, Jamaica Kincaid, Pauline Melville ja Erna Brodber, julkaisivat 1980-luvun aikana esikoisteoksensa. Aika merkitsi myös karibialaisen kirjallisuuden saattamista laajempaan tietoisuuteen esimerkiksi sen myötä, että useita antologioita ja kokoomateoksia julkaistiin. 1980-luvulla maastamuuton ja diasporisuuden teemat eli karibialaisen kulttuurin realiteetit siirtyivät myös kirjallisuuteen. Rotu, kolonialismi ja oma erityinen identiteetti, jonka nähtiin ammentavan hybridisyydestä, synkreettisyydestä ja karibialaisesta kansanperinteestä, muodostivat sen keskeiset lähtökohdat. Samalla alettiin etsiä omaa ja yhteisöllistä menneisyyttä sekä kirjoittaa uudelleen vaiennettua karibialaista historiaa. Persoonallinen ja poliittinen kietoutuivat toisiinsa ja "minä" nähtiin osana sosiaalista kontekstia.

Naiskirjallisuus alkoi huomioida erilaisia yhtäaikaisia alistuksen mekanismeja. Äideistä ja isoäideistä rakennettiin kätketyn menneisyyden kantajia ja tyttäret näyttäytyivät joko vieraantuneina etsijöinä tai vastarintaan kykenevinä sankarittarina. Merle Hodgen paikaltaan siirtyneen tyttösubjektin voidaan nyt ajatella kulkevan kohti feminististä ja taistelevaa tyttäryyttä - yhtäaikaisesti Yhdysvalloissa nousseen mustan feministisen estetiikan kirjailijoiden tyttöpäähenkilöiden tapaan. Transnationaaliset tilat ja identiteetit näyttävät asettuneen 1990- ja 2000-lukujen teoreettisten ja kirjallisten keskustelujen keskiöön. Esimerkiksi vuonna 1996 julkaistussa trinidadlaisen Shani Mootoon karibialaiseksi kulttiromaaniksi nousseessa teoksessa Cereus Blooms at Night naispäḧhenkilöiden niin sukupuoliset kuin kulttuurisetkin identiteetit liikkuvat ja liudentuvat samalla kun useat kerronnan tasot purkavat käsitystä yhdestä historiasta.

\section{Kehitysromaanin muoto ja paikoiltaan siirtyminen}

Miksi postkoloniaalinen kirjallisuus sitten hyödyntää yhä uudelleen Bildungsromanin genreä? Kehityskertomus tarjoaa mahdollisuuden tutkia omaa alkuperää, omia juuria ja, kuten Barney huomauttaa, pohtia sosiaalisen ympäristönsä elinvoimaisuutta ja arvioida uudelleen sosiaalisen eheytymisen näkymiä (Barney 1993, 361). Rakennettaessa jonkinlaista identiteettiä sosiaalisen syrjinnän ehdoilla, Bildungsromanin muoto toimii näiden ehtojen tarkastelussa. Genre mahdollistaa oivalluksen hetkiä tai tapoja käsitellä haavoittavia sanoja ja tekoja, joiden pitkäkestoisia seurauksia voidaan tarkastella päähenkilön tarinan edetessä. Rodun, sukupuolen, luokan, seksuaalisuuden 
tai yleisesti jonkinlaisten normaalin ja epänormaalin välisten rajojen väkivaltaisesti muotoilema minuus voidaan kohdata tarkastelemalla muotoutumisen prosessia sinänsä. (Ks. Barney 1993, 362.)

Perinteinen kehitysromaani pohjaa ajatukseen kehkeytyvästä minästä. Elämä on taiteen kaltainen laji, jossa voi kehittyä oppipojasta mestariksi (Master). Eurooppalaisessa kehitysromaanissa päähenkilö valitsee, hyväksyy ja hylkää katsomuksia tai arvoja sukeutuen kohti eheää minää. Postkoloniaalista todellisuutta kuvaavassa kehitysromaanissa tämä kehkeytyminen ei kuitenkaan aina kulje kohti ehyttä sulkeumaa vaan kohti säröisyyttä ja minän eri identiteettiakselien hankauskohtia. Kuten Maria Helena Lima ilmaisee, "growing up" on yhtä aikaa "growing away", poiskasvamista ihanteellisista (kolonialistisista) sosiaalisista rakenteista $(1993,434)$. Ihanteiden oppiminen ja määrittyminen merkitsee ymmärrystä niiden saavuttamattomuudesta, erosta ja tuskallisuudesta. Postkoloniaalisen Bildungsromanin voisi tulkita tämän häiritsevän välitilan ilmaukseksi tarjotessaan yhtä aikaa sekä mestarin että oppipojan interpellaatiota kolonisoidulle subjektille. Siirtyessään diasporaan kehitysromaanin lajirakenne heilahtaa paikaltaan kohti sitä ambivalenssia, joka on läsnä myös kolonisoidussa subjektivoinnin prosessissa. Ehkä juuri tästä syystä kehitysromaani on muodostunut niin elinvoimaiseksi genreksi postkoloniaaliseksi katsottavassa kirjallisuudessa.

Teoksessaan Ten is the Age of Darkness. The Black Bildungsroman (1995) Geta Leseur vertailee afrikkalais-amerikkalaista ja karibialaista kirjallisuutta. Leseurin mukaan afrikkalais-amerikkalaista ja karibialaista kokemusta on mahdotonta kuvata niillä "nurkkakuntaisilla" viitekehyksillä, jotka länsimainen kehitysromaani tarjoaa. Toisaalta kirjallisuudella, jota hän kutsuu termillä the black bildungsroman, ja eurooppalaisella kehitysromaanilla on toki myös paljon yhteistä, jonka takia onkin perusteltua puhua samasta lajityypistä (Leseur 1995, 19). Leseur esittää esimerkiksi, että molemmissa muodoissaan päähenkilöillä on usein yhteistä ikä tai matka syrjäseuduilta kaupunkeihin. ${ }^{4}$ Samankaltaisuuksiin kuuluu myös sijaisvanhemmuus ja tuntematon biologinen tausta, oppiminen, kotoa lähteminen, kehittymiseen kytkeytyvät tärkeät tai traumatisoivat sukupuoliset kokemukset, siirtyminen valistuneempaan paikkaan, muuttuminen tässä paikassa, mahdollinen paranoian kokeminen, matka ja lapsuuden maisemien jättäminen ja vierauden tai eristäytymisen tunne (mt. 19, 22). Leseur esittääkin juuri karibialaisen kehitysromaanin muotoutuvan lähimmäksi eurooppalaista Bildungsgenreä (mt. 12). Tässä on kyseessä taiteessa ja kulttuurissa ilmentyvä brittiläisen ja ranskalaisen "liberaalin imperialismin" politiikka, joka pohjasi ajatukseen kaikkien oikeudesta päästä osaksi emämaan sivistyksestä. ${ }^{5}$ Monilla Karibian saarilla toimikin sangen tehokas koulujärjestelmä. Silti, kuten Leseur huomauttaa, eurooppalaisessa ja karibialaisessa kehitysromaanissa on suuri ero (mt. 19).

Bildungsroman on laji, joka syntyi osaltaan individualistisen, modernin minuu- 
den manifestaatioksi, kuten esimerkiksi Liisa Saariluoma on useissa kirjoituksissaan osoittanut (ks. esim. Saariluoma 1999). Miten sitten poststrukturalistisen tietämisen tapoihin, identiteettiasemien moninaisuuteen ja valtadiskurssien kritiikkiin usein keskittyvä postkoloniaalinen teoriakenttä hyödyntää tai muuntaa kehitysromaanin lajia? Esitän seuraavassa joitain ehdotuksia tai tematisointeja siitä, miten postkoloniaalista kehitysromaania voisi määritellä tai käsitteellistää. Homi K. Bhabha käsittelee teoksensa Location of Culture artikkelissa "Signs Taken for Wonders" (1995) seikkaperäisesti koloniaalista läsnäoloa ja sen diskursiivista ja dominoivaa manifestoitumisen tapaa. Hän käyttää saksankielistä termiä Entstellung kuvaamaan kolonialististen instituutioiden asettamisen tapaa. Bhabhan mukaan tässä instituutioiden asettamisessa on aina läsnä myös paikoiltaan siirtymisen, väristymisen ja toiston näkökulmat (mt. 105). Bhabha pohtii kysymystä autoritäärisen symbolisen merkitsijän (jollainen esimerkiksi Bildungsromanin konventio voisi olla) siirtymistä paikoiltaan, kulttuurista toiseen. Bhabha kiinnittää huomiota siihen, miten tietyt kolonisoivan kulttuurin symbolista valtaa kantavat merkit toistetaan toisin ja eri tavoin siirtomaissa. Ne lakkaavat toimimasta vallan symboleina joutuessaan uudenlaiseen kontekstiin. Autoritääristen symbolien asettuessa vieraalle maaperälle ne muuntuvat ja joutuvat eroon niistä ehdoista, joissa ne ovat syntyneet. Autoritääristä symbolia ei enää tunnisteta eikä tunnusteta sellaiseksi, mikä johtaa symbolin muuntumiseen ambivalentisti merkitseväksi. (Mt. 110.)

Bhabhan mukaan siis koloniaalinen kulttuurituote saa siirtyessään horjuvan luonteen ja sitä alkaa merkityksellistää vääristyminen ja paikoiltaan siirtyminen (Bhabha 1995, 107). Tarkasteltaessa kehitysromaanin lajityyppiä tämä merkitsee tiettyä paradoksaalisuutta. Suhteessa valtaan kolonisoidut subjektit ovat jo sinänsä eron merkitsemiä, ei-valkoisia tai ei-eurooppalaisia. Miten väline, jota tutkimuksessa on usein pidetty individualistisen subjektin manifestoitumisen tilana ja joka siten on luomassa tätä eroa, voi samalla toimia tämän eron ilmaisukanavana? Esitän seuraavissa luvuissa esimerkkien avulla, että siirtyessään kontekstistaan kehitysromaani toimii paradoksaalisesti kolmiulotteisella tavalla. Ensinnäkin, se on rakentamassa kolonisoidun subjektin ambivalenssia tarjoamalla sellaisen minuuden mallin, joka ei tässä todellisuudessa täydellisty. Toiseksi, sen on samalla toimittava tämän ambivalenssin ilmaisun välineenä ja kolmanneksi tarjottava keinoja kyseisen ambivalenssin ylittämiseen. Kuten Maria Lima Gayatri Spivakia selvästi mukaillen huomauttaa, postkoloniaalisessa todellisuudessa kehitysromaani on sisäisesti paradoksaalinen laji, koska yrittäessään kuvata liikettä identiteetin hajaannuksesta kohti eheyttä se samanaikaisesta kieltää tällaisen eheyden mahdollisuuden (Lima 1993, 441-442).

\section{Kollektiivisuus ja oman perinteen muistaminen}

Mustien kirjailijoiden on ollut pakko pyrkiä tarkentamaan oman kansan erityistä 
tilannetta yhteisössä, joka perustuu valkoisiin arvoihin, ja rakentamaan tarkempaa kulttuurista kontekstia selventääkseen yksilöllisen Bildungin suuntaa. Näin ei-valkoisiin kehitysromaaneihin rakentuu etnografinen ja kollektiivinen sävy. Bildungsromanin traditio adaptoitiinkin Leseurin mukaan yhdysvaltalaisessa 1960-70-luvun kansalaisoikeustaisteluun kytkeytyvässä Black Aesthetics -liikkeessä (itse)ilmaisun välineeksi mustalle kulttuurille ja kansalle (Leseur 1995, 2). Tämän kollektiivisen, etnografisen Bildungin näen myös karibialaiselle kirjallisuudelle keskeisenä muotona. Lukuisista teoksista, jotka näyttävät kuvaavan esimerkiksi tyttösankarin kehittymistä naiseksi, rakentuu itse asiassa kudelma sellaisen kansan kollektiivista kehityskulkua ilmentäviä tarinoita, jonka historiaa ei tunneta länsimaissa. Tällaisia teoksia ovat esimerkiksi Michelle Cliffin Abeng (Jamaika), Ramabai Espinet'n The Swinging Bridge (Trinidad), Shani Mootoon He Drown She in the Sea (Trinidad), Merle Collinsin Angel (Grenada), Edwidge Danticatin Breath, Eyes, Memory (Haiti) tai Marie Elena Johnin Unburnable (Dominica), vain muutaman mainitakseni.

Karibialaisissa Bildung-adaptaatiossa keskeinen käsite on usein kollektiivinen muisti, jonka avulla yksilöllinen muistaminen ja kansallinen historiatietoisuus kytkeytyvät toisiinsa. Yksilön Bildung toimii metonymiana kollektiivisen tietoisuuden kehkeytymiselle. Kollektiivinen eli yhteisöllinen muistaminen tukee yksilön identifioitumista kolonisoituun yhteisöönsä. Kollektiivisen muistin tasolla yllä mainituissa romaaneissa korostuvat feministiset myytit, kansantarinat tai kertomukset radikaaleista vastatoimista, joissa naiset saavat subjektin aseman. Teoksissa kirjoittautuu näkyviin erityinen "musta naismuisti", jollaiseksi Karla Holloway nimittää etnisen tradition yhdistämän naisyhteisön (uudelleen)kerrottuja muistoja (ks. Billingslea-Brown 1999, 46). Muistamisen kuvausten voisikin sanoa muokkaavan narratiivisia muotoja ja luovan strategioita, joilla alistettu tai manipuloitu menneisyys voidaan käsitellä uudelleen. Esimerkiksi karibialaisen naiskirjallisuuden kontekstissa, kuten Johanna X. K. Garvey ilmaisee, muistaminen merkitsee sekä kolonisoijan että kolonisoidun miestoimijan unohtaman "Calibanin naisen" paikantamista uudelleen historiaan (Garvey 1999, 258).

Edellä mainituissa romaaneissa muistelun avulla rakentuu alistetun karibialaisen naisen toimijuus. Toimijuutta korostavat naisten poliittisen osallistumisen kuvaukset sekä yksilölliset muistot vallankumouksellisista tapahtumista. Kolonisoitu subjekti rakentaa identiteettiään suhteessa kolonialistiseen muistiin tai länsimaista subjektikäsitystä palvelevaan kehitysromaanin muotoon, joka näin rajoittaa subjektin ilmaisullista vapautta mutta tarjoaa samalla välineen ilmaisulle. Välineestä, eli tässä tapauksessa Bildungsromanin muodosta, adaptoituu bhabhalaisen Entstellungin prosessissa toiseuden tila. Roger Bromley huomauttaakin analysoidessaan aasialais-kanadalaista diasporaromaania, että kysymyksillään tilasta ja paikasta kulttuurienväliset tekstit nos- 
tavat esiin usein sivuutetun kollektiivisen itseyden, jolle länsimaisen Bildungsromanin individualistinen paradigma on asettanut rajoitteita (Bromley 2000, 113-114). Postkoloniaalisessa kehitysromaanissa niin kulttuurinen, historiallinen kuin maantieteellinenkin sijainti sekä tämän sijainnin tai paikantumisen uudelleenmäärittelyt ovat keskeisiä rakenteellisia seikkoja.

Paul Gilroyn mukaan romaanimuoto suhteutuu aina oman kulttuurinsa intresseihin, jolloin myös erilaiset kulttuurit rakentavat omanlaistaan romaanimuotoa. Amerikkalaisessa (ja karibialaisessa) mustassa kirjallisuudessa juuri kollektiivisen uudelleenmuistamisen ja muistelun teemat rakentavat fragmentaarista ja epälineaarista romaanikehystä. (Gilroy 1996/1993, 219.) Terry Dehay sen sijaan nimittää perinteistä realistista kerrontamuotoa "metakieleksi", jota vähemmistökirjailijoiden muistitarinat dekonstruoivat. Muistaminen on vastadiskursiivinen keino häiritä "metakielen" näkymätöntä järjestelmää ja rakentaa lukijalle kuva todellisuuden moniperspektiivisyydestä. Dehayn mukaan samalla kun moniäänisyydestä muodostuu keino haastaa hegemonisen tradition yhtenäisyys ja "vaatia" tilaa alistetulle kulttuuriselle identiteetille, kieltäytyvät etnisiin yhteisöihin kuuluvat kirjailijat hyväksymästä normatiivisia (länsimaisia) esitystapoja auktoriteetiksi. (Ks. Dehay 1994; 28, 30 ja 38.) Esimerkiksi Shani Mootoon romaanissa Cereus Blooms at Night päähenkilö Mala Ramchandinin tarina alkaa avautua häntä hoitavalle sairaanhoitajalle nykyisyydestä menneisyyteen päin. Malan mielen järkkyminen kuvataan muistipuheessa, joka katkoo romaanin nykytason kerrontaa. Tässä nykytasossa sen sijaan kehittyy sairaanhoitajan oma tarina, ja nämä molemmat kytkeytyvät taustalla rakentuvaan Lantanamacaran saaren kollektiiviseen historiaan. Leseur käyttää esimerkkinä kollektiivisuudesta afrikkalais-amerikkalaisessa naiskirjallisuudessa Toni Morrisonin romaania The Bluest Eyes (1970), jossa Pecola Breedloven tarina rakentuu Claudian kertomana. Niin Pecolan kuin Malankin antibildung kietoutuu Claudian, tai Mootoolla sairaanhoitajan, bildungiin (vrt. Leseur 1995, 128). Kuten Simone Alexander huomauttaa, muistin integroiminen on historian metakieleen tapa pitää elossa alistettu identiteetti. (Alexander 2001, 38.)

Jamaikalaisen Michelle Cliffin Bildungsroman Abeng (1984) muodostuu aikuisen kertojan muistipuheesta. Varttunut kertoja tarkastelee Clare Savagen lapsuutta, ja kertojan ääni muistuttaa paikoin ikään kuin aikuiseksi kasvaneen päähenkilön ääntä, intra- ja ekstradiegeettistä kerrontaa yhtä aikaa. Kertojan muistipuhe on kuitenkin oleellisesti muistamista uudelleen, muistojen korjaamista laajemman tietämyksen valossa. Kertoja osoittelee kohtia, joissa erilaiset (post)kolonialistiset valtamekanismit järjestävät muistipolitiikkaa. Samalla kertoja "muistaa" katkelmia karibialaisesta kollektiivisesta tarinasta keskeyttäen kerronnan esimerkiksi palasilla jamaikalaisten karanneista orjista muotoutuneen joukon, maroon-soturien, historiaa. Angelita Reyes huomauttaakin mustan naiskirjallisuuden muistavan "minän" sekoittuvan kollektii- 
viseen "me"-subjektiin (Reyes 2002, 31). Bildungs-genre vääristyy, Bhabhan ilmaisua soveltaakseni, kun autoritääristä merkkiä ei tunnusteta sellaiseksi, jolloin se on toisin toistettavissa ja se voi saada ambivalenttejakin merkityksiä. Sekä Bildung että Roman, sisältö ja muoto ovat tässä muuntuneet. Karibialaisesta kehitysromaanista rakentuu eräänlaista fiktiivistä auto/etnografiaa, joka kuvaa karibialaisen identiteetin löytämistä uudenlaisen menneisyyden rakentumisen yhteydessä. Tällaisessa autoetnografiassa yksilöllinen kehityskertomus ei dominoi yhteisöllistä vapautumista eikä kirjoittavasta minästä muodostu modernin diskurssin mukaista subjektia.

\section{Kirjallinen folklore ja isoäitien ääni}

Laajemman kollektiivisuuden osoitus on myös folkloren ja suullisena säilyneen perinteen läsnäolo tekstissä. Suullisesti välittyvää kreolikulttuuria kirjoitetaan (uudelleen) olevaksi samalla, kun se murtaa perinteistä lineaarista romaanikerrontaa. Suullinen traditio, myytit, naisten tarinat ja folklore nostavat esille rodullistettujen, kolonisoitujen ja unohdettujen naisten perinteen jatkuvuutta ja historiallisuutta. Kuten Gay Wilentz huomauttaa, saavutettuaan oikeuden kirjalliseen ilmaisuun mustat naiset ovat kääntyneet esiäitiensä tradition puoleen pyrkiessään rakentamaan historiallista representaatiota yhteisölleen. (Ks. Wilentz 1992, xi, xiv, xxv.) Tämä performatiivinen ääni on karibialaisessa nykynaiskirjallisuudessa usein feminististä vastadiskurssia - kreolinaisen vastapuhetta eli suullista traditiota, joka kutsuu hänet takaisin historiaan. Teoksissa äitien, isoäitien ja esiäitien tarinat ovat sellaista feminististä historiaa, joka huomioi naisten kulttuurisen kaksoistietoisuuden patriarkaalisen kielen ja feministisen äänen välissä, kuten esimerkiksi Erna Brodberin teoksessa Jane and Louisa Will Soon Come Home (1980). Teoksesta rakentuu folklorinen kokonaisuus, jonka kerrontaan kietoutuu jamaikalainen suullinen perinne, rituaalisuus, musiikki ja uskonnollisuus.

Sen sijaan teoksessa The Swinging Bridge isoäidin äänen etsintä rakentuu keskeiseksi osaksi Ramabai Espinet'n päähenkilön Bildungsprosessia. Päähenkilö Mona tuntee ahdistusta Kanadassa, mutta oivaltaessaan oman identiteettinsä kietoutuvan Intiasta siirtotyöläiseksi Trinidadiin tuodun isoäitinsä tarinaan hän ymmärtää syyn ahdistukseensa. Hänelle selviää, että hänen isoäitinsä on ollut randi, perinteisiä lauluja esittänyt laulaja. Mona voi jatkaa omaa elämäänsä vasta, kun kuulee näitä suullisena säilyneitä lauluja. Teos päättyy sanoihin:

I heard the beat of the hosay drum inside the steelband, heard chac-chac and dholak, dhantal, cuatro, and iron, coming to me in a rhythm that had transfixed me for hours. [---]. Sometimes, in the middle of my hustling city life, I pause just long enough to hear the edges of the beat pulsating at the outer corners of my mind. When I do, I know that I'm safe, memory intact, body alive, heart still felled by pain. $(\mathrm{SB}, 305 .)^{6}$

Teos osoittaa, miten tietty eheys tai turvapaikka on saavutettavissa, kun suulliseen ja 
kollektiiviseen perinteeseen löytyy yhteys: isoäitien laulu ja rytmi muuttuvat kuultaviksi ja omaan kieleen on etsiytynyt ilmauksia karibian-intialaiselle perinteelle. Sydämen tuska kertoo kuitenkin, ettei individualistinen täyteys ole saavutettavissa. Kolonialismin, murtuneen menneisyyden ja diasporan tuska jä.

Monista karibialaisista kehitysromaaneista rakentuu puhuvaa kirjallisuutta, johon Henry Louis Gates Jr. viittaa termillä "speakerly text". Suullisen tradition muodot ja paikallinen ortografia rakentavat erityistä dekolonisoivaa ja dialektista feminististä diskurssia, jossa länsimainen romaanimuoto yhdistyy paikalliseen ilmaisuun ja jolla vähemmistön kokemuksesta on mahdollista kirjoittaa. (Ks. Gates 1988, xxiii ja Wilentz 1992, xvii ja xxii.) Samalla kirjailijoista itsestään tulee yhteisölleen eräänlaisia ääniä, jotka sekä yhtäältä kirjoittavat näkyviin unohdetun tradition että toisaalta asettavat sen hybridiseen dialogiin länsimaisen diskurssin kanssa varioiden näin kolonisoitua kieltä dekolonisoiviin tarkoituksiin. Karibialaisen folkloren hybridiset henkilöhahmot sekä niissä kuvattu kreolisoitunut perinne ovat vastakertomuksia valkoisille mytologioille - tai kuten Bhabha artikuloi, heterogeenisten kysymysten paikkoja, jotka murtavat autoritaarisen diskurssin staattisuutta ja määrittelyjä. (Bhabha 1995, 116.) Tarinat ovat strategisia vastakertomuksia kolonisoidulle historian kirjoittamiselle, ja tarinankerronnan aktilla on rituaalinen merkitys. Ne edustavat yhteisöllisyyttä, yhteen liittymistä, suullisen perinnön jatkumista, naisten kulttuurin tunnustamista sekä vastarintaa. Rituaalinen tarinankertoja tai kirjailija, joka muuntaa kansanperinnettä kirjalliseksi folkloreksi, on kolonisoidun subjektin yhdistäjä "interpellaatiossa" diasporiseen yhteisöönsä, mikä on keskeistä myös henkilökohtaisessa Bildungsprosessissa.

Viimeaikaisessa karibialaisessa naiskirjallisuudessa isoäitien hahmoista rakennetaan feministisen vastarinnan ja karibialaisten naisten kulttuuritradition genealogiaa. Kirjalliset isoäiti-hahmot eivät usein ole niinkään biologisia isoäitejä kuin erilaisia othermother-hahmoja, esiäitihahmoja, folklorisia soturi-äitejä, parantajia, spirituaalisia johtajia, nimettömäksi jän̈neitä naisia, orjia, kasvattiäitejä, isotätejä ja muita vanhempia naishahmoja, joiden matrilineaarisen perinteen luo tyttären tai tyttärentyttären on kuljettava Bildungsprosessissaan. Kanadalais-trinidadilaisen Dionne Brandin teoksessa In Another Place, not Here (1996) päähenkilö kuulee tarinan Afrikasta tuodusta esiäidistään, joka ei suostunut nimeämään yhtään kasvia, puuta tai lintua uudessa maassa. Tytön tarve nimetä nämä esiäidin puolesta sysää käyntiin hänen kasvuprosessinsa. Karibialaisessa naiskirjallisuudessa Bildungsprosessin haasteena voisikin nähdä uudenlaisen äidinmaan rakentamisen sekä siirtomaavallan demytologisoinnin emämaana. Brittiläisellä Karibialla siirtomaavallasta käytetään usein nimitystä mothercountry, siinä missä isoäidit yhdistyvät omaan äidinmaahan, motherland.

Isoäitien, äitien ja tytärten suhteet ovat karibialaisessa naiskirjallisuudessa usein hyvin metaforisia. Erittäin yleinen tapa on kuvata äidin ja tyttären problematiikkaa 
metaforisena esityksenä siirtomaan ja kolonisoidun suhteesta. Äiti saattaa olla valkoisten ihanteiden läpitunkema tai niistä liian haavoittunut opettaakseen tyttärelleen välineitä vastarintaan. Vastauksena on usein kääntyminen kohti isoäidin traditiota. Kincaidin romaanissa Annie John samannimisen päähenkilön kiinteä suhde äitiin alkaa rakoilla tyttären ollessa mustasukkainen isänsä ja äitinsä suhteesta. Teoksessa kuvataan suhteen kriisiytyminen metaforisesti tytön sairastumisena. Hän alkaa kuitenkin parantua, kun paikalle tuodaan isoäiti Ma Chess, joka vielä hallitsee perinteisen parantamisen tradition. Teos päättyy kuitenkin siihen, että Annie lähtee kotisaareltaan Antigualta Englantiin. Loppu on yhtä aikaa harmoninen ja epäharmoninen. Annie muistelee lapsuuttaan lämmöllä. Hän on antanut äidilleen anteeksi mutta kokee samalla, ettei hänen vanhempiensa talossa eikä koko saarella ole hänelle tilaa. Bildung-prosessi kuljetetaan siis lähtemiseen, mikä on hyvin tavallista Karibialaisessa naiskirjallisuudessa, "growing up is growing away".

Kolmen sukupolven teema - isoäidin vastatraditio, kolonisoitu äiti ja feministinen tytär - näyttää yleistyvän 1980 -luvun kirjallisuudessa. ${ }^{8}$ Simone A. James Alexander yhdistää postkoloniaalisessa kirjallisuudessa rakennettavan äidinmaan Benedict Andersonin käsityksiin kuvitteellisesta yhteisöstä, johon liittyvät niin kulttuuriset, spirituaaliset kuin kollektiivisetkin arvot. Äidinmaa on pikemminkin jatkuvuutta, toveruutta ja yhteisöllisyyttä korostava diasporisen kansan keskinäinen suhde. (Alexander 2001, 2 ja 8-12.) Esittäisinkin, että karibialaisessa naiskirjallisuudessa tämän matrilineaarisen ja folklorisen kytköksen löytäminen kollektiiviseen traditioon, on erityinen postkoloniaalinen Bildungsproblematiikan muoto.?

\section{Paikantumisen problematiikka ja alistetun kehityskriisi}

Kuten jo aiemmin totesin, kysymys tilasta, paikasta ja paikantumisesta on postkoloniaalisessa, usein diasporaa kuvaavassa kehitysromaanissa keskeinen. Suhde omaan saareen, lähtö tai konkreettinen paluu sinne on toistuvasti eräänlainen Bildungprosessin päätepiste. Claude McKayn klassikkoromaanissa The Banana Bottom on tyypillinen juonirakenne, jossa päähenkilö Bita Plant oivaltaa tietyn minän kokonaisuuden kokemisen olevan seurausta paluusta kotisaarelle seitsemän vuoden "värässä paikassa" olemisen jälkeen. Saaren tuoksut, maut ja äänet luovat lujan tunteen minän kytkeytymisestä paikkaan. Tällainen paluu ja minän yhteys karibialaiseen luontoon ja ympäristöön toistuvat uudestaan ja uudestaan postkoloniaalista identiteettiä rakentavassa, erityisesti uudemmassa naiskirjallisuudessa. Cliffin No Telephone to Heaven (1987), Espinet'n The Swinging Bridge, Mootoon He Drown She in The Sea, Paule Marshallin Brown Girl, Brownstones (1959), Maryse Condén I, Tituba, Black Witch of Salem (1986) tai Edwidge Danticatin Breath, Eyes, Memory (1994) voisi mainita esimerkeiksi teemojen hyödyntämisestä. Toisaalta aiemmin mainittu negatiivinen 
Bildung ei ole harvinainen karibialaisessa kirjallisuudessa, sillä monet, erityisesti varhaisemmat, teokset jättivät kuvaamatta jonkinlaisen paluun tai eheytymisen teeman. Sen sijaan teokset rakentuivat kuvaamaan kolonisoidun subjektin hajaannusta, lähtöä ja hidasta valumista "displacementin" eli väärässä paikassa olemisen tilaan. ${ }^{10}$ Näin ne päättyvät usein lähtöön saarelta, kuten Merle Hodgen kuuluisa teos Crick Crack Monkey tai Lammingin klassikkoromaani In the Castle of My Skin.

Paikantumista ja paikaltaan siirtymistä väittäisinkin karibialaisen postkoloniaalisen kehitysromaanin keskeiseksi piirteeksi ja samalla keskeiseksi eroksi traditionaaliseen Bildungsromaniin. Paikantumisen problematiikka tematisoi yhtä aikaa sekä kolonialistisen tieto-valta-järjestelmän kolonisoitua subjektia syrjäyttävää voimaa, karibialaista kreolisoitunutta ja diasporista kulttuuria että paikaltaan siirtyneen kirjallisuuden lajin murtunutta mimesiksen tapaa. Lima esittää tulkinnassaan Kincaidin Annie John -romaanista, että tunnistamattomaksi jäävä kaipuu ja melankolisuus, jota kertoja ei osaa nimetä, on varsin tavallista karibialaiselle kehitysromaanille. Näihin piirteisiin/ tunteisiin kiteytyy postkoloniaalisen naiskirjallisuuden käsittelemätön suru menetettyä (iso)äitiä tai kotimaata kohtaan (Lima 1993, 448). Paikantumattomuuden tunne ja sitä tematisoiva matrilineaarisen perinteen puute artikuloituvat essentiaalisena kodittomuutena, kuten Jean Rhysin teosten päähenkilöillä. Karibialaista kehitysromaania voisi kutsua Elaine Savoryn termein ex/isle -kirjallisuudeksi, jossa irtaantumisen ja paikantumisen teemat ikään kuin kamppailevat (Savory 1998, 170). Tähän paikantumisen problematiikkaan on kytkettävissä myös karibialaisessa kirjallisuudessa tavallinen tapa nimetä kehitysromaani paikan mukaan, kuten aiemmin mainitut The Banana Bottom ja Miguel kadun väkeä tai sijaintiin viittaavasti, kuten In Another Place, Not Here tai Brown Girl, Brownstones.

Bildungsproblematiikaksi kutsutaan usein teoksen keskeiseen kehityskriisiin kytkeytyvää ongelmaa, joka aiheuttaa päähenkilölle ahdistusta ja joka sysää etsimään jonkinlaista eheyttävää ratkaisua oman minuutensa harmonisoimiseksi sekä suhteessa itseensä että suhteessa sosiaaliseen ympäristöönsä. Liisa Saariluoma puhuukin teoksessaan Modernin minän synty 1700-luvun romaanissa minän ja maailman välisestä aidosta ongelmasta eli yhteiskunnan ja yksilön välisestä ristiriidasta, johon kehitysromaani etsii ratkaisua (Saariluoma 1999, 36 ja 85). Postkoloniaaliselle kehitysromaanille yleensä, ja karibialaiselle naiskirjallisuudelle erityisesti, tyypillinen Bildungsproblematiikka koskee oman monitahoisen alistuksen huomaamista ja toiseuden positioon kasvamista. Nuoret tytöt joutuvat varhain toteamaan sukupuoleen, seksuaalisuuteen, miehiin, ihonväriin, äitiyteen tai kulttuuritaustaan kytkeytyvät moninaisen marginalisoinnin mekanismit. Geta Leseur kuvaa tällaista Bildungsproblematiikkaa lainaamalla Paule Marshallia, jonka mukaan ”tytöt näyttävät pelkäävän kasvamista, muita ihmisiä ja elämää, mikä johtaa heidän vetäytymiseensä omaan maailmaansa” (Leseur 1995, 4). 
Juuri tällainen on esimerkiksi Pecola Breedloven tarina Morrisonin teoksessa The Bluest Eyes.

Leseurin mukaan ei-valkoisessa naiskirjallisuudessa tyttösankarit saattavat varhain kuvitella itsensä johtajina tai menestyneinä aikuisina, mutta joutuvat kipeiden kypsymisvaiheiden (rites of passage) kautta huomaamaan yksilöllisen vapautensa kapeuden. Michelle Cliffin romaanissa No Telephone to Heaven kuvataan tilanne, jossa erittäin älykkäänä pidetty hyvin vaaleaihoinen kreolipäähenkilö Clare Savage on aloittamassa uutta koulua Yhdysvalloissa. Hänen ihonvärinsä vaivaa koulunjohtajaa, joka kertoo, mitä lääkäri asiasta ajattelisi:

He would call you white chocolate........... mean, have you ever seen a child's expression when he finds a white chocolate bunny in his Easter basket? $\mathrm{He}$ simply doesn't understand.... He thinks it strange. I do not want to be cruel, Mr. Savage, but we have no room for lies in our system. No place for in-betweens. (NTH, 99 kursiivi lisätty.)

Clarea nimitetään valheeksi, ja hän oppii, ettei systeemissä ole sijaa hänen kaltaisilleen. Individualistiseen eheyteen ei ole pääsyä systeemissä, jossa identiteetin eri akselit asettuvat ristiriitaisiin asemiin ja jossa sosiaaliset rajat marginalisoivat subjektia. Identiteetin rakentamisen välineeksi ja Bildungsproblematiikan ratkaisuun on löydettävä keinoja toimia näillä rajoilla, niistä tietoisena. Leseur huomauttaakin, että ei-valkoiset tytöt joutuvat huomaamaan, että fyysinen kauneus, luokka, sukupuoli ja ihonväri ovat rajoja, joiden yli on päästävä mutta jotka toimivat tyttöhahmoille epäedullisella tavalla. Itsemäärittelyä on rakennettava ristiriitaisilla, jopa vihamielisillä raja-alueilla, mikä heijastuu myös Bildungsromanin muotoon ja kehitysvaiheiden erilaisuuteen. Mustien naisten kehitysromaaneissa päähenkilöiden on yritettävä määritellä uudenlaisia olemisen tapoja kulttuuristen stereotyyppien ja historiallisten kategorisointien ulkopuolelta. (Leseur 1995, 14 ja 101-2). Tällainen "toiseutta kohti kehkeytyvä" minuus tuottaa postkoloniaaliseen kehitysromaaniin aiemmin mainitsemani surullisen initiaation prosessin. Itsemäärittelyn sääntelyä teoksissa tapahtuu siis niin muodon kuin sisällönkin tasolla. ${ }^{11}$

Paradoksaalisesti Bildungsromanista rakentuu karibialaisen kirjallisuuden traditiossa sekä kolonisoiva että dekolonisoiva lajityyppi. Myös kirjallisen genren voi tulkita siirtyvän diasporaan ja muuntuvan kolonisoitua kokemusta tai fragmentoituneita identiteettejä kuvaavaksi välineeksi. Postkoloniaalinen kulttuuripiiri ei ole passiivinen vaikutteiden vastaanottaja. Karibialla kehitysromaanista on tullut väline ilmaista kolonisoituun identiteettiin kytkeytyvää problematiikkaa, mutta samalla ilmaisun muotokonventiot, jotka liimautuvat tiukasti moderniin individualismiin, sääntelevät vapautta tähän itseilmaisuun. Yhteenvetona onkin todettava, että ainutkertaisen minän rakentamisen välineeksi muotoutunut Bildungsroman epäonnistuu emansipatorisessa prosessissaan 
siirtyessään pois syntykontekstistaan. Postkoloniaalisessa kirjallisuudessa siihen alkaa kytkeytyä uusia piirteitä, joilla on potentiaalia muuttaa lajirakennetta. Näistä uusista piirteistä olen nimennyt ensiksikin kollektiivisemman subjektikäsityksen ja etnografisemman otteen, toiseksi paikan, paikattomuuden ja kulttuurisen sijainnin keskeisen merkityksen päähenkilölle, kolmanneksi folklorisen perinteen ja esivanhempien edustaman tradition sekä neljänneksi alistetun subjektin kehityskriisin, jossa päähenkilö joutuu kokemaan tavoiteltavien ideaalien olevan itselleen mahdottomia.

Lopuksi yhdyn Maria Liman $(1993,432)$ argumenttiin. Hänen mukaansa myös narratiiviset muodot tarvitsevat uusia topografioita, joita voidaan tarkastella erilaisissa subjektivointien prosesseissa ja diasporisissa sosiaalisissa tai poliittisissa konteksteissa. Genretutkimus tarvitseekin siis sijainnin politiikkaa. Kuten Lima ilmaisee, genren rajat ovat kuin prisman heijastuma peilistä. Ne tarjoavat omaa muotoaan piirtyvälle kuvalle (1993, 432-433). Karibialaisessa naiskirjallisuudessa kehitysromaanista on muodostunut oleellisesti hybridinen tarinamuoto, joka heijastelee individualistisen emansipaation ihannetta. Niissäkin teoksissa, joissa subjektivoinnin prosessi on antagonistinen tai melankolinen, tämä antagonismi saa muotonsa sitä määrittelevän eheyden ihanteen kautta. Kuten Charlotte Brontën Kotiopettajattaren romaanissa, karibialaisen Bertha Masonin henkinen kaaos heijastuu Jane Eyren järjestyneeseen kehitysprosessiin, jossa hän alkuperänsä kadotettuaan oppii tietyt ihanteet ja saavuttaa lopulta harmonisen minuuden - seestyneen miehen rinnalla tietenkin.

\section{Viitteet}

${ }^{1}$ Käytän muiden postkoloniaaliseen teoriakenttään kytkeytyvien tutkijoiden tavoin kursivoitua muotoa termistä Bildungsroman alleviivatakseni lajin saksalaista alkuperää. Ajatus "alkuperästä" näyttää olevan edelleen 2000-luvulla aina läsnä keskusteltaessa kehitysromaanista. Harvoihin kirjallisuuden genreihin liittyy tällainen autenttisuuden mystifiointi, tai kuten Susan Fraiman uskaltautuu ehdottamaan, Wilhelm Meisterin alkuperäisyyden fetissointi (ks. Lima 1993, 431).

${ }^{2}$ Négritude-liike syntyi Pariisissa karibialaissyntyisten taiteilijoiden ja opiskelijoiden keskuudessa. Se liittyy laajemmin 1930-luvun taiteen avantgardistisiin suuntauksiin, jotka kyseenalaistivat vallitsevaa eurooppalaista kulttuurielämää. Termi négritude esiintyy ensimmäisen kerran Aimé Césairen teoksessa Cahiers d'un retour au pays natal (1939).

${ }^{3}$ Ks. esim. Baugh, Edward 1995, 63-75.

${ }^{4}$ Leseur tulkitsee siirtymisen maalta kaupunkiin olevan keskeinen sekä eurooppalaisessa että mustassa kehitysromaanissa. Siinä missä siirtyminen maalta kaupunkiin saattoikin olla keskeistä karibialaiselle kirjallisuudelle hyvinkin pitkään, tällainen liikkeen suunta on vaikeammin havaittavissa enää 1990- ja 2000-lukujen kirjallisuudessa. Tässä uudemmassa kirjallisuudessa korostuu nähdäkseni toistuva neuvottelu oman kulttuurisen sijainnin kanssa. Liikkeen suunta on pikemminkin edestakainen matkustelu saaren ja metropoliin välillä.

${ }^{5}$ Tämä johti tietenkin myös siihen, että joillain hyvin menestyneillä nuorilla on mahdollisuus 
päästä stipendien turvin brittiläisiin ja pariisilaisiin yliopistoihin. Euroopasta ammennettiin taiteeseen paljon virikkeitä, joten karibialainen taide on ollut pitkään aivan eri tavoin eurooppalaista kuin afrikkalais-amerikkalainen taide. Samoin karibialainen älymystö on ollut alueen kokoon ja koulutustasoon nähden laajaa, esimerkiksi Claude McKay, V.S Naipaul, Frantz Fanon, Edouard Glissant, Aime Cèsaire, Orlando Patterson, Patrick Chamoiseau tai Stuart Hall kuuluvat näihin stipendiaatteihin.

${ }^{6}$ Tässä esimerkissä tulee esiin myös monien karibialaisten kirjailijoiden tapa käyttää kieltä monimerkityksellisesti. Vieraat sanat, kuten dholak ja dhantal kuvaavat toisaalta länsimaisen lukijan välimatkaa tekstiin, mutta toimivat myös kommunikaationa, kuten Françoise Lionnet huomauttaa. Se, mikä karibialaiselle lukijalle on viesti, saattaa länsimaiselle lukijalle merkitä "häiriöääntä" tekstissä - ja päinvastoin. (Ks. Lionnet 1992, 331-334.) Lionnet kutsuu lingvistiseksi arkeologiaksi kertojien tapaa nostaa esiin erilaisia sanoja ja selittää niiden merkityksiä ja käyttöä kielessä (Lionnet 1992, 340). Lingvistinen arkeologia kommunikoi länsimaiselle lukijalle kielenkäytön moninaisuutta ja rakentaa jamaikalaiselle lukijalle historiallisen perspektiivin omaan kreolikieleen. Kaikki kirjailijat eivät tätä kommunikointia kuitenkaan tee. Esimerkiksi Brodber ei selvennä lukijalle folklorisen kielensä vierasta sanastoa tai kreolijamaikan syntaksia. Länsimaisen lukijan vieraus korostuu entistä enemmän. (Ks. kulttuurisesta välimatkasta karibialaisen romaanin kielessä Valovirta 2006).

${ }^{7}$ Marjorie Pryse analysoi klassikkoteoksessa Conjuring mustaa naiskirjallisuutta eräänlaisena näkyjen loihtimisena. Kaunokirjallisuuden pohjalla olevat folkloriset ja maagiset kertomukset käsitetään taiteena, joka kirjallisuuteen siirrettynä loihtii esiin uudenlaisen kuvan menneisyydestä. (Ks. Pryse 1985, 2.) Mustat naiskirjailijat itse muuttuvat Prysen mukaan maagisiksi tarinankertojiksi, jotka välittävät edelleen äitiensä ja isoäitiensä traditiota. (Pryse 1985, 5.)

${ }^{8}$ Äidin maan ja äitien ja tytärten suhteet ovat olleet myös karibialaisten naiskirjallisuuden tutkimuksen keskiössä. Ks. esim. Rody 2001, Alexander 2001, Daly \& Reddy 1991, MacDonald-Smythe 2001, Nasta 1991, Reyes 2002.

${ }^{9}$ Tämä on äidin tradition etsintä on keskeistä erityisesti karibialaisia tyttösankareita kuvaavissa Bildungsromaneissa. Äiti Afrikka -teema eli alkuperän myytin maternalisointi on kuitenkin eittämättä tyypillistä mustassa karibialaisessa kirjallisuudessa sen varhaisista vaiheista asti. Esimerkiksi Aime Césairen Négritude-estetiikassa Afrikka, afrikkalainen maa ja juuret ovat essentialistisesti feminiinisiä, äitiyden metaforiikan kautta kuvattuja.

${ }^{10}$ Tämäntyyppisiä rakenteita on analysoitu paljon myös feministisessä tutkimuksessa. Modernista feministisestä kritiikistä käsin tarkasteltuna myös perinteinen eurooppalainen naissankaria kuvaava Bildungsroman tarjoaa epätyydyttävän kehitystarinan.

Naiskehitysromaanille tyypillinen Bildungsprosessi kuvaa tytön kehityksen potentiaaliseksi "lainrikkojaksi", eli hänen sivistymisensä ohittaa staattiselle naiseudelle varatun aseman.

Kehityskulun saattaminen loppuun merkitsee sankarittaren seestymistä avioliittoon ja vaimon rooliin, joka ymmärretään lopulta ainoaksi oikeaksi ratkaisuksi. (Kleinbord Labovitz 1986, 4-5). Klassinen esimerkki tällaisesta tarinasta on Charlotte Brontën Jane Eyre (1847), jossa Janen kehityskulun taustalle jää juuri karibialainen kreolinainen, henkiseen hajaannukseen ajautuva Bertha Mason.

${ }^{11}$ Erityispiirteitä voisi toki määritellä monia muitakin. Olen tässä halunnut keskustella isommista ja lähes aina toistuvista erityispiirteistä. Kuitenkin esiin voisi nostaa myös esimerkiksi karibialaisen Bildungsromanin tavan kuvata kohtalaisen suppeaa jaksoa sankarin 
elämästä, jatko-osien tai toisten osien yleisyyttä tai tapaa kuvata päähenkilö vähemmän aktiiviseksi oman elämänsä toimijaksi kuin eurooppalaisessa kehitysromaanissa. Yksi mielenkiintoisimmista eroavista piirteistä on Maria Liman nimeämä karibialaisen romaanin tapa käynnistää Bildungsprosessi pikemminkin kuolemasta kuin syntymästä. Toinen hänen nimeämänsä vastaava piirre on kehitysromaanin genreen kytkeytyvä päähenkilön lukuharrastus. Tämä on eurooppalaisessa kehitysromaanissa sankaria kehittävä ja rakentava ominaisuus siinä missä se postkoloniaalisessa Bildungissa merkitsee ahdistusta aiheuttavaa ja minäkuvaa hajottavaa toimintaa, jossa kolonisoijan ihanteet tukahduttavat päähenkilöä. (Ks. Lima 1993, 441 ja 443.)

\section{Lähteet}

\section{Kaunokirjallisuus}

BRAND, Dionne 1997 (I996): In Another Place, not Here. Toronto: Vintage Canada. Brodber, ERna I993 (I980): Jane and Louisa Will Soon Come Home. London: New Beacon Books. Brontë, CHARLOTTE I980 (i 847): Jane Eyre. London: Oxford University Press. Cliff, MiCHelle i 984: Abeng. New York: Plume. Cliff, MiChelle i 987: No Telephone to Heaven (=NTH). New York: Plume. ESPINET, RAMABAI 2003: The Swinging Bridge (=SW). Toronto: Harper Collins Publishers ltd.

HODGE, MERLE I997 (I970): Crick Crack Monkey. London: Heinemann. KINCAID, JAMAICA I 997 (I985): Annie John. London: Vintage.

LAMming, GeORge 2004 (I970): In the Castle of My Skin. Ann Arbor: University of Michigan press, Ann Arbor Paperbacks.

marshall, paule i997 (I959): Brown Girl, Brownstones. New York: The Feminist Press.

mCKay, ClaUde 1999 (I933): Banana Bottom. New York: A Harvest Book. моотоO, Shani 1999 (I996): Cereus Blooms at Night. London: Granta Books. MORRISON, TONI I 972 (I970): The Bluest Eyes. New York : Washington Square Press. RHYS, JEAN I968 (I966): Wide Sargasso Sea. Harmondsworth : Penguin Books.

\section{Tutkimuskirjallisuus}

ALDRICH, ROBERT I995: "From Francité to Créolité. French West Indian Literature Comes Home.” Teoksessa Russel King, John Connell, Paul White (eds.), Writing across Worlds: Literature and Migration. London: Routledge, 101-124.

ALEXANDER, SIMONE A. JAMES 200I: Mother Imagery in the Novels of Afro-Caribbean Women. Columbia: University of Missouri Press. 
BARNEY, RICHARD A. I 993: "Subjectivity, The Novel, and The Bildung Blocks of Critical Theory”. Genre. Vol. XXVI (Winter). 459-375.

Baugh, Edward i995: "The Sixties and Seventies." Teoksessa Bruce King (ed.), West Indian Literature. London: Macmillan, 63-75.

BНАВНА, НОмі К. I995/I994: Location of Culture. London: Routledge. billingslea-brown, alma jean i999: Crossing Borders Through Folklore. African American Women's Fiction and Art. Columbia: University of Missouri Press.

Bromley, roger 2000: Narratives for a New Belonging. Diasporic Cultural Fictions. Edinburg: Edinburg UP.

DALY, BRenda O. \& REDdy, MaUReen T. (eds.) I99I: Narrating Mothers. Theorizing Maternal Subjectivities. Knoxville: University of Tennessee Press.

DEHAY, TERRY I 994: "Narrating Memory." Teoksessa Amritjit Singh, Joseph T. Skerrit \& Robert E. Hogan (eds.), Memory, Narrative, \& Identity. Boston: Northeastern UP, 26-44.

GaRVEY, JOHANNA X. K. I999: "Passages to Identity. Re-Membering the Diaspora in Marshall, Phillips, and Cliff." Teoksessa Maria Diedrich, Henry Louis Gates Jr. \& Carl Pedersen (eds.), Black Imagination and the Middle Passage. New York: Oxford UP, 255270.

Gates, henry louis JR. I988: The Signifyin(g) Monkey. A Theory of African American Literary Criticism. New York: Oxford UP.

gilroy, paul 1996/1993: The Black Atlantic. Modernity and Double Consciousness. London: Verso.

KLeinbord Labovitz, ESTHer I986: The Myth of the Heroine: The Female Bildungsroman in the Twentieth Century. New York: Peter Lang Publishing.

LESEUR, GeTA I995: Ten Is the Age of Darkness. The Black Bildungsroman. Columbia: University of Missouri Press.

LIMA, MARIA helena I993:"Decolonizing Genre: Jamaica Kincaid and the Bildungsroman". Genre. Vol. XXVI (Winter). 431-459.

LIONNET, FRANÇOISE I992:"Of Mangoes and Maroons: Language, History; and the Multicultural Subject of Michelle Cliff's 'Abeng'." Teoksessa Sidonie Smith \& Julia Watson (eds.), DE/Colonizing the Subject: The Politics of Gender in Women's Autobiography. Minneapolis: University of Minnesota Press, 321-345.

macdonald-smythe, antonia 2002: Making Home in the West/Indies. Constructions of Subjectivity in the Writings of Michelle Cliff and Jamaica Kincaid. New York: Garland Publishing Inc.

susheila NASTA (ED.) I99I: Motherlands. Black Women's Writing from Africa, the Caribbean and South Asia. London: The Women's Press.

PRYSE, MARJORIE I985: "Introduction. Zora Neale Hurston, Alice Walker, and the 
'Ancient Power' of Black Women.” Teoksessa Marjorie Pryse \& Hortence J. Spillers (eds.), Conjuring. Black Women, Fiction, and Literary Tradition. Bloomington: Indiana UP, $1-24$.

Reyes, Angelita 2002: Mothering Across Cultures. Postcolonial Representations. Minneapolis: University of Minnesota Press.

RODy, CAROLINE 200I: The Daughter's Return. African-American and Caribbean Women's Fictions of History. New York: Oxford UP.

SAARILUOMA, LIISA I999: Modernin minän synty 1700-luvun romaanissa. Valistuksesta Wilhelm Meisteriin. Helsinki: Suomalaisen kirjallisuuden seura.

SAVORY, ELAINE I998: "Ex/isle: Separation, Memory, and Desire in Caribbean Women's Writing." Teoksessa Adele S. Newson \& Linda Strong-Leek (eds.), Winds of Change. The Transforming Voices of Caribbean Women Writers and Scholars. New York: Peter Lang Publishing Inc., 169-177.

VAlOvirTa, ELINA 2006: "'Oudot' tunteet: Affektiivinen feministinen lukijateoria ja karibialainen naiskirjallisuus." Naistutkimus-Kvinnoforskning. Vol. 19 (3). 4-16.

WILENTZ, GAY I992: Binding Cultures. Black Women Writers in African and the Diaspora. Bloomington: Indiana UP. 